\title{
Hatha Yoga Sebagai Terapi Alternatif Pada Nyeri Kepala
}

\author{
Ni Wayan Yusi Armini ${ }^{1}$, Diah Nirmala Dewi ${ }^{2}$ \\ Universitas Hindu Negeri I Gusti Bagus Sugriwa Denpasar \\ email: yusiarmini14@gmail.com ${ }^{1}$, diahnirmala@uhnsugriwa.ac.id ${ }^{2}$
}

Diterima tanggal 29 Januari 2021, diseleksi tanggal 7 Maret 2021, dan disetujui tanggal 30 Maret 2021

\begin{abstract}
Headaches often suddenly attack and this causes disruption to the various activities that are being carried out by ours. Headaches are pain in the head that can occur gradually or appear instantly almost unexpectedly. Headaches that appear can be felt light, heavy, and the area can be felt in the entire head or only in certain areas. There are many ways to deal with headaches, such as get some medication or get some massage therapy at certain points area, depending kind of headaches. However, the use of pain medication usually only has a short-term impact, so that at any time this headache reappears. Yoga therapy is an alternative in dealing with this headache. Yoga is indeed known as an alternative healing for certain diseases, one of them is headache. Although there is no exact and in-depth research on this issue, but some yoga movements are said to be able to deal with headaches, especially for those who often experience this headache attack at the wrong time, for example.
\end{abstract}

\section{Keywords: headaches; yoga; alternative therapy}

\section{ABSTRAK}

Sakit kepala seringkali datang secara tiba-tiba dan hal ini menyebabkan gangguan terhadap berbagai macam aktivitas yang sedang dilakukan. Sakit kepala merupakan rasa nyeri dibagian kepala yang bisa terjadi secara bertahap maupun muncul seketika. Sakit kepala yang muncul pun bisa terasa ringan, berat, dan areanya pun bisa terasa di seluruh kepala ataupun hanya daerah tertentu. Banyak cara untuk mengatasi sakit kepala, mulai yang dengan konsumsi obat-obatan pereda rasa sakit hingga melakukan terapi pijat di titik-titik tertentu. Namun penggunaan obat pereda rasa sakit biasanya hanya memberi dampak jangka pendek, sehingga sewaktu-waktu nyeri kepala ini timbul kembali. Terapi yoga menjadi salah satu alternatif dalam menangani nyeri kepala ini. Yoga memang dikenal sebagai alternatif penyembuhan untuk penyakit-penyakit tertentu, salah satunya rasa sakit kepala. Meskipun belum ada penelitian eksak dan mendalam soal ini, namun beberapa gerakan yoga dikatakan mampu dalam menangani sakit kepala, khususnya bagi mereka yang sering mengalami serangan sakit kepala ini pada waktu yang kurang tepat, pada saat beraktivitas misalnya.

Keyword: nyeri kepala; yoga; terapi alternatif 


\section{PENDAHULUAN}

Kesehatan adalah keadaan dimana tubuh terbebas dari segala macam gangguan, penyakit baik fisik maupun mental, dan juga keadaan sejahtera bagi manusia secara komperhensif dikehidupanya. Tanpa tubuh yang sehat, akan sulit bagi individu dalam menjalankan aktivitas sehari-hari. Meskipun demikian, dalam keadaan tertentu manusia juga tak bisa menghindar dari ancaman dan gangguan yang menyerang tubuh yang sehat. Salah satu penyakit yang paling sering menyerang manusia adalah sakit kepala. Dalam sebuah penelitian, diperkirakan bahwa 7 dari 10 orang pernah mengalami sakit kepala setidaknya sekali dalam setahun. Hal ini berbanding lurus dilapangan, bahwa sakit kepala merupakan penyakit yang paling umum diderita, bisa dilihat dari banyaknya persedian obat sakit kepala mulai dari apotek hingga warung kelontong (Refdinal, 2006:2).

Nyeri kepala bisa terasa ringan hingga berat, dan dapat berlangsung beberapa jam hingga berhari-hari. Nyeri kepala atau headache atau sefalgia adalah suatu rasa nyeri atau rasa yang tidak enak pada daerah kepala, termasuk meliputi daerah wajah dan tengkuk leher (Perdossi, 2013). Umumnya sakit kepala dapat diobati dengan obat-obatan. Namun untuk sakit kepala yang dipicu oleh penyakit serius, diperlukan penanganan lebih lanjut. Pengobatan untuk sakit kepala bervariasi, tergantung pada gejala yang dialami dan penyebabnya. Namun, sebagian besar sakit kepala bukan merupakan gejala dari kondisi medis yang serius, sehingga bisa diatasi dengan obat-obatan yang dijual bebas yang dapat mengurangi gejalanya. The Atlas of Headache Disorders menyajikan data yang diperoleh oleh WHO bekerja sama dengan Lifting The Burden: the Global Campaign againts headache. Data - data dikumpulkan dalam bentuk survei kuesioner dari ahli saraf, praktisi umum dan perwakilan pasien dari 101 negara, dilakukan dari Oktober 2006 sampai Maret 2009. Hasil yang diperoleh yaitu gangguan nyeri kepala termasuk migrain dan nyeri kepala tipe tegang, merupakan gangguan yang paling sering terjadi. Studi prevalensi memperkirakan setengah sampai tiga perempat dari orang dewasa berusia 18 - 65 tahun di dunia telah memiliki nyeri kepala pada tahun lalu. Menurut studi ini, lebih dari 10\% memiliki migrain, dan 1,7-4\% dari populasi orang dewasa dipengaruhi oleh nyeri kepala selama 15 hari atau lebih pada setiap bulannya. Di seluruh dunia, sekitar 50\% dari orang-orang dengan nyeri kepala lebih memilih untuk mengobati dirinya sendiri dan tidak menghubungi praktisi kesehatan. Sampai dengan $10 \%$ populasi dunia berkonsultasi ke ahli saraf, meskipun hanya sedikit di negara Afrika dan Asia Tenggara. Tiga penyebab konsultasi untuk nyeri kepala, baik 
perawatan primer dan spesialis yaitu migrain, nyeri kepala tipe tegang dan kombinasi keduanya (Goadsby, 2002).

Berbagai macam jenis nyeri kepala dan klasifikasi sakit kepala, mayoritas orang masih memilih menangani sakit kepala dengan mengonsumsi obat pereda rasa sakit, seperti parasetamol dan ibuprofen dengan merek dagang yang variatif dipasaran. Selain itu, pengunaan cara tradisional seperti, minum jamu, pijat akupressure, dan yoga juga merupakan alternatif untuk menangani rasa nyeri di bagian kepala ini. Cara-cara seperti ini merupakan pilihan bagi mereka yang tidak bisa mengonsumsi obat generik. Yoga merupakan salah satu alternatif untuk mengatasi rasa sakit kepala ini. Hal ini dikarenakan yoga menawarkan metode pendekatan terhadap ketiga aspek dalam tubuh, dan yang berhubungan dengan rasa sakit kepala ini adalah stress. Definisi stress adalah sebuah keadaan yang di alami ketika ada sebuah ketidaksesuaian antara tuntutan-tuntutan yang diterima dan kemampuan untuk mengatasinya (Looker \& Gregson, 2005: 44). Hans Selye (dalam Sugara, 2016: 81) mendefinikan stress sebagai reaksi nonspesifik tubuh terhadap ancaman, dimana ketika mampu beradaptasi dengan ancaman itu dsebut eutress (stress yang sehat), jika tidak bisa beradaptasi disebut distress (stress yang tidak sehat).

Stress merupakan penyebab sakit kepala paling umum, lebih-lebih di masyarakat urban. Penyebab stress pun beragam mulai dari tuntutan hidup, pekerjaan, dan masalah lain yang umum di lingkungan masyarakat sosial perkotaan (Parviz Bahrami, 2012). Sehingga dengan menggunakan pendekatan holistik melalui terapi yoga, sakit kepala tidak hanya dihilangkan rasa nyerinya saja namun juga ditangani hingga ke akar-akarnya. Ini karena yoga merupakan terapi komplementer yang berpusat pada gerakan, nafas, dan konsentrasi (meditasi), sehingga pikiran, fisik, dan psikis saling bersinergi untuk menjaga kesehatan tubuh melalui distribusi energi yang stabil dan seimbang. Yoga asanas merupakan salah satu alternatif dalam menghilangkan sakit kepala sekaligus relaksasi tubuh, pikiran, dan jiwa. Yoga asanas juga menyediakan jalan untuk mengembangkan bathin dalam mencapai kesadaran diri sehingga asanas dapat membantu menenangkan pikiran (Vivekananda, 2012:2). Dengan ini terapi yoga dengan yoga asanas akan memberi dampak positif dalam memanajemen stress.

\section{PEMBAHASAN}

\subsection{Nyeri Kepala}

Sakit kepala atau nyeri kepala adalah nyeri yang dirasakan di daerah kepala atau merupakan suatu sensasi tidak nyaman yang dirasakan pada daerah kepala (Goadsby, 2002). Nyeri kepala atau headache atau sefalgia juga menilmbulkan rasa nyeri atau rasa yang tidak enak pada daerah kepala, termasuk meliputi daerah wajah dan tengkukleher (Perdossi, 2013). Nyeri 
kepala umumnya diklasifikasikan sebagai nyeri kepala primer dan nyeri kepala sekunder, kemudian dibagi menjadi beberapa jenis nyeri kepala tertentu. Gangguan nyeri kepala primer adalah nyeri kepala yang sifatnya "idiopatik", nyeri kepala yang tidak terkait dengan kondisi patologi atau penyebab lain yang mendasari. Berdasarkan pemeriksaan neurologis dan tes pencitraan biasanya normal, tidak peduli seberapa parah gejala. Kejadian nyeri kepala primer lebih sering terjadi dibandingkan nyeri kepala sekunder. Nyeri kepala sekunder adalah nyeri kepala yang dikaitkan dengan kondisi patologis yang mendasari, seperti adanya tumor otak, aneurisma, penyakit inflamasi. Dengan pemeriksaan neurologis dan tes pencitraan telah terbukti membantu dalam diagnostik nyeri kepala sekunder.

Nyeri kepala merupakan salah satu gejala yang paling sering ditemui dalam praktik dokter umum, dengan tingkat konsultasi 4,4/1000 (Susanto, 2014). Nyeri kepala diklasifikasikan menjadi tiga jenis, yaitu nyeri kepala primer, sekunder, serta nyeri neuropati kranial, nyeri wajah dan nyeri kepala lain. Primary headache dibagi menjadi migren, tension-type headache (TTH), trigeminal autonomic cephalgia, dan kelainan nyeri kepala primer lainnya. Sedangkan secondary headache dibagi berdasarkan kausal penyebabnya, yaitu yang disebabkan oleh trauma kepala atau leher, penyakit vaskular kranial atau servikal, penyakit intrakranial non-vaskular, akibat obat-obatan atau gejala putus obat, infeksi, dan lain sebagainya (Tepper, 2013).

Gejala sakit kepala adalah sakit atau nyeri di kepala, yang bisa menyebar ke wajah, leher, dan bahu. Penglihatan penderita juga dapat menjadi buram, serta lebih sensitif terhadap cahaya dan suara. Segera periksakan diri ke dokter bila sakit kepala disertai muntah, leher kaku, gangguan penglihatan, bicara kacau, atau kejang. Bisa jadi hal tersebut merupakan gejala dari penyakit yang berbahaya. Sakit kepala termasuk gejala umum yang paling sering dialami manusia. Menurut World Health Organization (WHO), sekitar 50\% dari populasi orang dewasa di dunia mengalami gejala ini. Artinya, hampir setengah masyarakat dunia pernah mengalaminya. Rasa sakit di area kepala bisa menyerang siapa saja, mulai dari anak-anak hingga dewasa dan lanjut usia (lansia). Baik wanita dan pria memiliki kesempatan yang sama untuk mengalami gejala ini.

\subsection{Klasifikasi Sakit Kepala}

Jenis dari setiap sakit kepala dibedakan sesuai lokal dan intensitas nyerinnya. Klasifikasi dan kriteria diagnostik headache dikeluarkan oleh International Headache Society (IHS) tahun 2013 dalam wujud ICHD-3 (The International Classification of Headache Disorders 3rd edition). Bagi dokter dan para tenaga kesehatan, klasifikasi dari nyeri kepala ini merupakan patokan dasar untuk menganalisa dan membuat diagnostik dari nyeri kepala yang diderita oleh 
pasiennya. Oleh IHS, nyeri kepala dikelompokkan menjadi 3 kategori umum, yaitu Nyeri kepala Primer (Primary Headaches), Nyeri kepala Sekunder (Secondary Headaches), dan Nyeri kepala dengan neuropati kranial, nyeri wajah lain dan nyeri kepala lainnya (Painful cranial neuropathies, other facial pains andother headaches).

\section{a. Sakit kepala primer}

Sakit kepala primer adalah jenis yang paling sering dialami oleh banyak orang. Sakit kepala primer biasanya terjadi akibat gangguan langsung pada area luar kepala, aktivitas hormon yang diproduksi otak, maupun masalah dalam struktur kepala seperti gangguan saraf atau pembuluh darah yang mengelilingi tengkorak. Selain itu, sakit kepala ini dapat disebabkan oleh macam-macam gangguan pada otot yang berada di sekitar kepala dan leher. Bahkan, sakit kepala ini bisa saja terjadi akibat kombinasi akan berbagai faktor tersebut. Satu yang pasti, sakit kepala primer tidak dipicu atau disebabkan oleh kondisi kesehatan lain yang mendahului. Akan tetapi, tidak menutup kemungkinan kemunculan jenis sakit kepala primer dapat dipengaruhi riwayat kesehatan keluarga. Artinya, sakit kepala yang satu ini bisa diturunkan melalui genetik.

Sakit kepala primer itu sendiri memayungi beberapa jenis turunannya, yaitu tension headache, migrain, dan cluster headache:

\section{Nyeri kepala tegang (tension headache)}

Sakit kepala yang satu ini termasuk jenis primer yang paling umum dan paling sering terjadi. Biasanya dimulai perlahan hingga rasa sakit memuncak di siang hari. Orang yang mengalami tension headache umumnya akan merasa kepalanya seperti ditekan atau menggunakan pengikat kepala yang cukup kencang di sekitar kepala. Selain itu, rasa sakit yang dialami menjalar dari atau menuju ke leher.

\section{Migrain}

Migrain sendiri terbagi atas dua jenis, yaitu migrain tanpa aura dan dengan aura. Migrain tanpa aura umumnya akan membuat kepala terasa seperti berdenyut-denyut dan hanya terasa di salah satu bagian kepala, kiri atau kanan. Rasa sakit karena migrain biasanya disertai dengan pandangan mata yang buram, sakit yang terasa ringan, mual, hingga gangguan sensori. Migrain bisa bertahan selama beberapa jam saja hingga 2-3 hari. Migrain adalah salah satu jenis sakit kepala primer yang cukup sering terjadi dan memiliki dampak yang cukup berpengaruh pada kehidupan seseorang yang mengalaminya.Sementara, migrain dengan aura adalah kondisi di mana sebelum atau tepat saat migrain terjadi, ada gejala berupa kilatan cahaya atau bintik-bintik cahaya saat Anda memandang suatu objek sehingga menganggu penglihatan. Gejala aura juga bisa menyebabkan mati rasa pada wajah dan tangan Anda. 


\section{Sakit kepala cluster (cluster headache)}

Kondisi yang satu ini biasanya muncul secara tiba-tiba, bisa hanya satu kali hingga delapan kali dalam sehari. Rasa sakit yang timbul biasanya bertahan selama 15 menit hingga tiga jam lamanya. Kondisi ini bisa berlangsung selama berminggu-minggu hingga berbulan-bulan. Namun, mungkin saja setelah beberapa waktu terjadi sakit kepala cluster, tidak ada gejala muncul sama sekali. Bahkan, Anda bisa saja tidak mengalami rasa sakit selama berbulan-bulan hingga bertahun-tahun. Cluster headache biasanya menyebabkan rasa sakit yang cukup parah, bahkan mungkin memberikan sensasi seperti terbakar pada area kepala. Rasa sakit ini biasanya terletak di area sekitar mata.

\section{Sakit kepala skunder}

Nyeri kepala sekunder merupakan nyeri kepala yang dikarenakan penyakit lain sehingga terdapat peningkatan tekanan intrakranial atau nyeri kepala yang jelas terdapat kelainan anatomi maupun struktur.Sementara itu, sakit jenis ini umumnya adalah gejala dari suatu kondisi kesehatan lain yang dapat mengaktifkan saraf yang sensitif terhadap rasa sakit di kepala. Hal ini berarti kondisi ini bisa menjadi pertanda dari masalah kesehatan lainnya.

Banyak sekali kondisi kesehatan yang dapat menjadi penyebab munculnya kondisi ini, termasuk tumor otak, pendarahan di otak, hingga serangan panik dan glaukoma. Misalnya, jika sakit tidak bisa diatasi dengan penggunaan obat dan lebih mengganggu dari rasa sakit yang pernah muncul sebelumnya. Bahkan, rasa sakit juga disertai oleh demam, kekakuan pada otot leher, di beberapa kondisi sakit kepala sekunder termasuk sakit akibat sinus, rebound headache, dan rasa sakit yang datang secara tiba-tiba.

\subsection{Patofisiologi Sakit Kepala dan Faktor Penyebab}

Patofisiologi atau Penyebab nyeri kepala terdapat di nosiseptor meningeal dan neuron trigeminal sentral. Sebagian besar pembuluh darah intrakranial mendapatkan inervasi sensoris dari ganglion trigeminal, dan menghasilkan neuropeptida yang akan mengaktivasi nosiseptor nosiseptor. Neuropeptida yang dihasilkan seperti CGRP (Calcitonin Gene Related Peptide) yang paling besar dan diikuti oleh SP (substance P), NKA (Neurokinin A), PACAP (Pituitary Adenylate Cyclase Activating Peptide, nitricoxide (NO), molekul prostaglandin E2 (PGEJ2), bradikinin, serotonin (5-HT) dan adenosin triphosphat (ATP). Batang otak merupakan organ yang memiliki peranan penting dalam transmisi dan modulasi nyeri baik secara ascending maupun descending. Periaquaductal grey matter, locus coeruleus, nucleus raphe magnus dan reticular formation yang berada di batang otak akan mengatur integrasi nyeri, emosi dan respons otonomik. Sehingga dapat dikatakan batang otak merupakan generator dan modulator sefalgi. 
Sakit kepala disebabkan oleh aktifnya saraf nyeri di kepala, baik akibat gangguan di kepala maupun bagian tubuh lain. Aktifnya saraf nyeri ini bisa dipicu oleh aktivitas zat kimia di otak, gangguan pada otot di kepala dan leher, atau gangguan pembuluh darah di kepala. Seperti yang divisualisasikan dalam gambar 1. Rangsangan yang menganggu diterima oleh nosiseptor (reseptor nyeri) polimodal. Rangsangan di bawa menuju cornu dorsalis cervical atas transmisi dan modulasi nyeri terletak pada batang otak (periaquaductal grey matter, nucleus raphe magnus, formasio retikularis) Hipotalamus dan sistem limbik memberikan respon perilaku dan emosional terhadap nyeri pada talamus hanya terjadi persepsi nyeri dan terakhir pada korteks somatosensorik dapat mengetahui lokasi dan derajat intensitas nyeri.

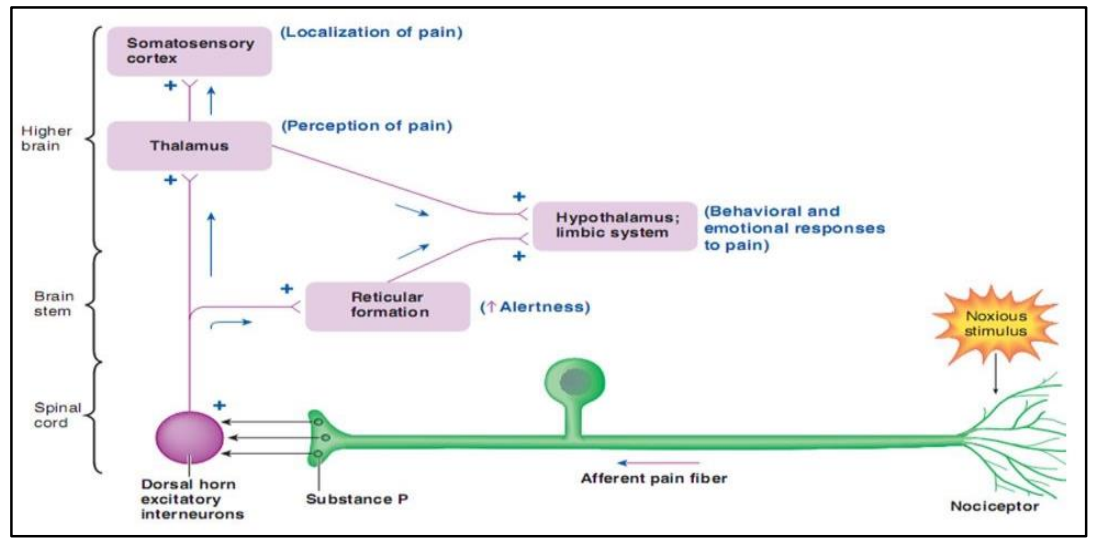

Gambar 1. (sumber : undip.ac.id/syifasabillaj)

Adapun faktor penyebab dari timbulnya sakit kepala ini adalah perilaku atau gaya hidup, maupun suatu kondisi atau penyakit. Beberapa perilaku yang dapat memicu timbulnya sakit kepala antara lain:

1. Konsumsi minuman beralkohol.

2. Konsumsi minuman berkafein secara berlebihan.

3. Kebiasaan mengikat rambut teralu kencang atau mengenakan helm yang sempit.

4. Perubahan pola tidur atau kurang tidur.

5. Telat makan

6. Kebiasaan merokok.

7. Olahraga berlebihan, terutama yang dilakukan di dataran tinggi atau ketika cuaca sedang panas.

Sedangkan penyakit-penyakit yang dapat mengakibatkan keluhan sakit kepala, di antaranya:

1. Penyakit di otak, contohnya adalah stroke, tumor otak, radang otak, meningitis, dan kelainan bentuk atau peradangan pembuluh darah otak. 
2. Penyakit di area wajah. Penyakit yang dimaksud dapat berupa sinusitis, glaukoma, infeksi telinga, penyakit trigeminal neuralgia, sakit gigi, atau flu.

3. Penyakit di jantung, contoh penyakit jantung adalah penyakit jantung koroner.

4. Gangguan mental, ini dapat berupa gangguan panik, serangan panik, gangguan cemas, gangguan tidur, dan depresi.

Selain hal-hal di atas, ada juga sejumlah kondisi lain yang dapat mengakibatkan atau memicu sakit kepala, seperti: Stres, Hipertensi, Berat badan berlebih., Dehidrasi, Keracunan zat kimia, Cedera kepala, Konsumsi pil KB, Menstruasi.

\subsection{Terapi Yoga Untuk Menyembuhkan Yoga dan Nyeri Kepal}

Yoga secara harfiah berasal dari suku kata "yuj” yang memiliki arti menyatukan atau menghubungkan diri dengan Tuhan. Kemudian Patanjali memberikan definisi tentang yoga yaitu mengendalikan gerak-gerak pikiran. Yoga Asanas menyediakan jalan untuk mengembangkan batin dalam mencapai kesadaran diri sehingga Yoga asanas dapat membantu menenangkan pikiran (Vivekananda, 2012:2).Yoga memiliki banyak sekali manfaat bagi kesehatan tubuh. Diantaranya membuat lebih peka dan konsentrasi, membantu ibu hamil, peningkatan spiritual, mengatasi depresi, menurunkan berat badan dan masih banyak lagi.

\subsubsection{Yoga}

Yoga adalah upaya praktis dalam menyelaraskan tubuh, pikiran dan jiwa. Konsep ini bisa dilihat dengan kata dalam bahasa Sansekerta yang menjadi induknya, "Yug" yang berarti "menggabunkan" atau "mengharmonikan". Dengan kata lain pengertian secara garis besar dari kata yoga adalah usaha mengharmonisasikan elemen spiritual dan fisikal seorang manusia untuk mencapai kondisi edial. Fase penyatuan ini akan memudahkan terjadinya harmoni dengan lingkungan sekitar (sesama makhluk serta alam) dan Sang Maha Pencipta. Walaupun dikenal pertama kali berasal dari India, tetapi yoga sangat aplikatif dilakukan seluruh umat manusia secara universal.

Yoga juga merupakan sarana latihan fisik dan mental yang bertujuan untuk menyeimbangkan dan menyatukan antara lahir, batin, dan pikiran. Maha Resi Patanjali dalam kitabnya, Yogasutra (I.2) mendefinisikan yoga adalah "mengendalikan gerak-gerik pikiran". Artinya, yoga adalah cara untuk mengendalikan tingkah polah pikiran yang cenderung liar, bias dan lekat terpesona oleh aneka ragam objek (yang di khayalkannya) memberi nikmat. Ini berarti seorang yang melakukan yoga harus mampu berkonsentrasi penuh, mengatur dan mengontrol guna menciptakan keselarasan dan keseimbangan antara jiwa, pikiran dan tubuh. 
Ada beberapa aliran yoga yang bisa disesuaikan dengan kebutuhan masing-masing orang. Namun pada pembahasan kali ini kita akan lebih menekankan pada Hatha Yoga yaitu jenis yoga yang paling sering kita temui dan mempunyai empat teknik yaitu Asana (gerak), Pranayama (olah nafas), Bandha (kuncian), dan Mudra (gestur). Jenis yoga ini latihannya ringan dengan melibatkan setiap sendi tubuh dalam gerakannya yang bertujuan untuk memperkuat, melonggarkan dan menyeimbangkan anggota tubuh.

\subsubsection{Yoga Asanas}

Secara umum manfaat yoga yaitu untuk fisik jaringan endokrim yang penting tersebut dikendalikan dan diatur sehingga sejumlah hormon yang berbeda dikeluarkan dari semua kelenjar dalam tubuh. Meningkatkan denyut jantung, aliran darah dan aliran oksigen ke tubuh, meningkatkan metabolisme sel, meningkatkan metabolism endokrin, meningkatkan produksi hormon. Asanas (gerak) membuat tubuh lentur dan mampu mengatur dirinya dengan mudah untuk mengubah lingkungan. Fungsi-fungsi pencernaan dirangsang agar jumlah yang tepat dari getah-getah pencernaan dirangsang agar jumlah yang tepat dari getah-getah percernaan (air liur, enzim dan lain-lain) mengalir. System saraf simpatis dan parasimpatis dibawa kedalam keadaan yang seimbang agar organ-organ dalam yang mereka kendalikan tidak terlalu aktif maupun kurang aktif.

Asanas mempengaruhi setiap aspek fisik manusia, tidak saja membuat seimbang kerja kelanjar tetapi juga membuat otot-otot giat dan santai, begitu pula dengan sistem saraf, menstimulir sirkulasi, mengendurkan otot dan memusatkan pikiran. Selama melakukan gerakangerakan yang halus ini, tubuh tetap berada dalam keadaan efisien yang rileks dan pernapasan panjang yang menyertai sikap-sikap ini membuat darah menyerap lebih banyak oksigen. Selama melakukan asanas, tenaga lebih banyak dikumpulkan daripada dikeluarkan.

Asanas, sebagai kebalikan dari olah raga yang selama ini ada melibatkan kontraksi otot tertentu, dipertahankan dalam jangka waktu tertentu dan diikuti oleh perasaan yang rileks dan nafas yang halus. Setelah melakukan gerakan asanas yang cukup lama, maka otot-otot akan menjadi rileks. Rileksasi yang sempurna dari gerakan asanas dapat menghemat energi yang dapat dikumpulkan oleh tubuh untuk meningkatkan pikiran mencapai kesadaran kosmis.

\subsubsection{Pose asanas untuk sakit kepala.}

Latihan yoga asana pada Hatha Yoga melancarkan aliran darah, dan oksigenasi sel otot di kepala. Sawasana dan meditasi mampu menurunkan tonus saraf simpatis, meningkatkn tonus system saraf parasimpatis serta menurunkan tekanan darah, menurunkan stress sehungga nyeri kepala berkurang. Saat melakukan yoga, tarikan napas yang tenang dan dalam dapat membantu mengendurkan otot-otot tubuh yang menegang. Begitu pula saat menggerakkan leher, bahu, dan 
tulang belakang saat yoga, hal ini dapat membuat aliran darah menjadi lebih lancar. Akibatnya, rasa sakit dan stres yang dirasakan jadi berkurang, sehingga dapat mengurangi dan menghilangakan rasa sakit kepala.

Sebagaimana dikutip dari The Huffington Post, Lynn A. Anderson memaparkan bahwa setiap gerakan yoga yang memiliki kontraksi pada otot-otot yang terlibat dalam terjadinya nyeri kepala akan lebih di relaksasikan dan dengan aliran darah yang lancar, maka suplai oksigen pada sel otot akan maksimal sehingga dapat mengurangi rasa nyeri tersebut. Dan berikut gerakan atau pose-pose yoga asanas yang dapat mengkontraksikan, melemaskan aliran darah dan oksigen meningkat. Metabolism sel meningkat sehingga otot lebih segar serta mampu menghilangkan sakit kepala:

\section{a. Cat pose (marjaryasana)}

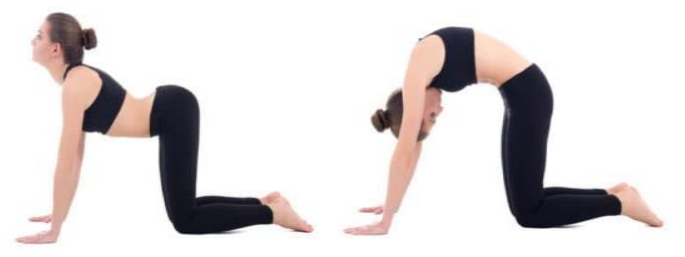

Sumber : hello sehat

Gerakan yoga yang mirip dengan postur kucing ini dapat membantu melancarkan aliran darah pada tubuh bagian atas. Ini juga bisa merilekskan otot-otot punggung, bahu, dan leher yang memicu sakit kepala. Mulailah dengan posisi merangkak seperti gambar di atas. Pastikan pergelangan tangan sejajar lurus di bawah bahu dan jari-jemari terbuka lebar, sementara posisi lutut berada di bawah pinggul. Dorong punggung ke atas saat mengembuskan napas, lalu tarik kembali tulang belakang ke posisi semula sembari menarik napas.

\section{b. Eagle pose (garudasana)}

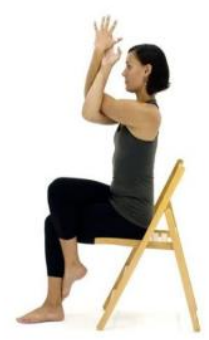

Sumber ; livewell.com

Gerakan sederhana ini bermanfaat untuk meredakan otot tubuh bagian atas yang menegang, terutama di bagian pundak. Pertama-tama, cari posisi ternyaman Anda dengan duduk bersila atau duduk di atas kursi. Putar lengan seperti pada gambar, lalu biarkan otot bahu dan tangan menjadi lebih fleksibel dan rileks 


\section{c. Seated forward bend (paschimottanasana)}

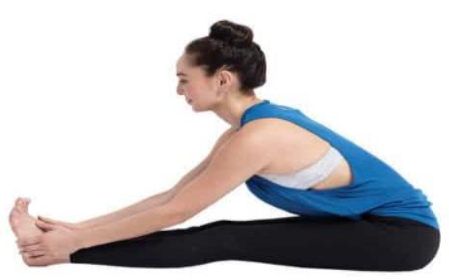

Sumber: yogajournal.com

Paschimottanasana mencakup keseluruhan sistem di tubuh dan sangat berguna untuk diabetes dan tekanan darah tinggi. Asana ini juga memberi seluruh tubuh peregangan yang baik. Menariknya, bagian depan bodi disebut Timur, dan bagian belakangnya biasanya disebut Barat. Asana ini berkonsentrasi di bagian belakang tubuh, dan oleh karena itu, dinamai seperti itu. Gerakan ini dapat membantu melancarkan aliran darah ke jantung. Pasalnya, jantung harus bekerja sangat keras untuk memompa darah dan oksigen ke otak dan tubuh bagian atas. Semakin lancar aliran darah ke jantung, semakin lancar pula aliran darah ke otak dan mengatasi sakit kepala Anda.

\section{d. Child pose (balasana)}

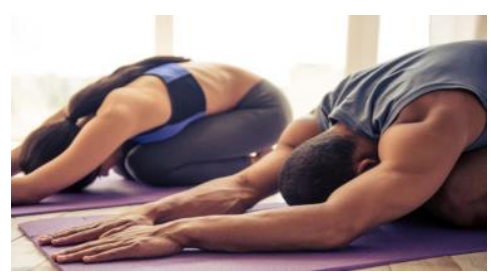

Sumber: hellosehat

Dengan melakukan child pose, Anda akan membalikkan gaya gravitasi ke arah atas sehingga mendorong oksigen lebih banyak ke bagian leher, bahu, dan punggung. Karena itulah gerakan ini bisa Anda manfaatkan sebagai obat alami untuk mengatasi stres, kecemasan, hingga sakit kepala.

\section{e. Legs up the wall pose (viparita karani)}

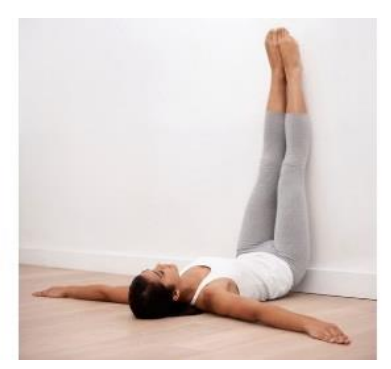

Sumber: verywell-fit.com

Pose ini termasuk gerakan yoga terbaik untuk mengatasi kecemasan. Pose yang mengharuskan menaikkan kaki ke dinding ini dapat membantu menenangkan pikiran dan 
mengurangi kelelahan. Lagi-lagi, ini berhubungan dengan membalikkan gaya gravitasi supaya aliran darah ke otak, metabolism otak, regenerasi sel saraf otak meningkat serta fungsi sel saraf otak optimal.

\section{f. Knees-to-chest pose (apasana)}

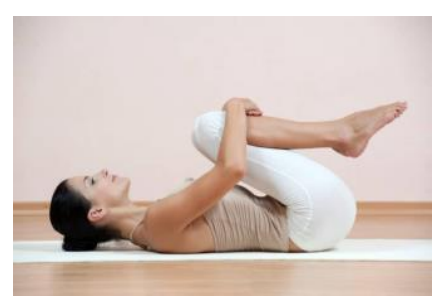

Sumber: hello sehat

Gerakan yoga ini dengan menarik lutut ke arah dada dan menahannya selama 30 sampai 60 detik. Selama pose ini, dianjurkan untuk mengatur napas dalam-dalam supaya tubuh jadi lebih rileks. Pose knees-to-chest ini berfungsi untuk melonggarkan otot-otot punggung. Aliran darah ke seluruh tubuh pun jadi lebih lancar, terlebih saat berhasil menarik dan membuang napas secara teratur dan lebih tenang.

\section{g. Seated spinal twist (ardha matsyendrasana)}

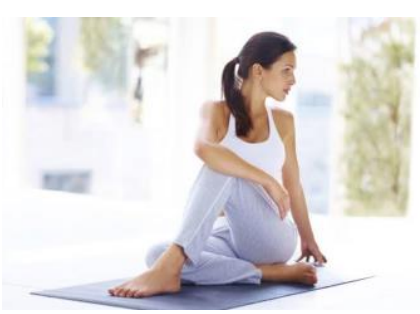

Sumber: Mother-Mag.com

Pose yoga yang satu ini menyimpan banyak manfaat yang sayang untuk dilewatkan. Selain mampu mengatasi sakit kepala, gerakan yoga ini dapat membantu melancarkan sistem pencernaan juga. Caranya luruskan kaki kiri ke depan, lalu silangkan kaki kanan ke arah samping kaki kiri. Luruskan tangan kanan dengan menyentuh lantai, sementara tangan kiri menumpu di atas lutut kanan. Ulangi gerakan yang sama untuk kaki kanan.

\section{h. Head to knee pose (janusirsasana)}

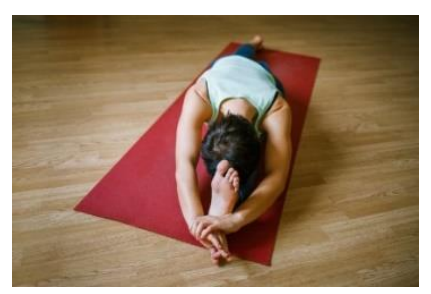

Sumber: Hello sehat

Head to knee pose dapat meningkatkan aliran darah dan meregangkan otot-otot tubuh yang menegang. Caranya, tekuk kaki kanan hingga membentuk sudut 90 derajat, sementara kaki 
kiri diluruskan. Dorong punggung ke arah kaki kiri, dan usahakan kedua tangan berhasil menyentuh jari-jari kaki. Tahan posisi ini selama 60 detik, lalu lakukan hal yang sama dengan kaki kanan. Bila dilakukan secara rutin, bisa merasa lebih tenang dan bertenaga setelah melakukan yoga ini.

Semua pose yoga asanas diatas dapat dijadikan alternatif terapi pada penderita sakit kepala, terutama yang memiliki tingkat tegang yang tinggi dan memiliki level stress yang tinggi. Gerakan-gerakan diatas dapat dikombinasikan dengan olah napas (Pranayama) sehingga suplai okseigen kedalam sel-sel terdistribusi dengan baik dan sistem otot dan hormon pun dapat menerima energi yang cukup. Selain itu, setelah melakukan pose asanas dengan durasi yang menyesuaikan setiap orang, diakhiri dengan corpes pose atau savasana untuk merileksasikan tubuh dan mengamati aliran energi yang keluar masuk tubuh. Setelah semua terapi dengan yoga asanas selesai, lakukan meditasi untuk menguatkan fokus dan konsentrasi, sehingga dapat memanajemen stress, yang merupakan penyebab utama sakit kepala, dengan baik.

\section{PENUTUP}

Nyeri kepala yang merupakan penyakit yang paling umum yang sering diderita oleh banyak orang. Jenis-jenis sakit kepalapun beragam, begitu juga dengan penanganan penyembuhannya. Namun sakit kepala paling banyak diakibatkan oleh ketegangan otot dan tingkat stress yang tinggi. Hal ini memang dapat disembuhkan dengan pengobatan konvensional, seperti dengan meminum obat pereda rasa sakit yang banyak beredar di pasaran maupun dengan terapi pemijatan pada titik-titik tertentu sesuai dengan kondisi sakit kepala tersebut.

Namun ternyata ada alternatif yang lebih baik dan dapat digunakan sebagai sarana pencegahan terhadap sakit kepala. Hatha yoga dapat digunakan sebagai alternative untuk mengatasi nyeri kepala. Pandangan yoga klasik fokus di aktivitas yang mengembangkan insight untuk memahami kebenaran mengenai diri manusia sedang pandangan hatha yoga fokus di aktivitas yang mengembangkan kesehatan fisik dan psikologis (Stiles, 2002). Untuk mendapat hasil yang maksimal secara fisik, psikilogis dan spiritual, orang yang melakukan yoga dianjurkan untuk berlatih dengan dua konsep tersebut (Stiles, 2002). Hatha yoga juga merupakan salah satu mekanisme program dimana penyatuan dari tubuh (body), pikiran (mind) dan jiwa yang nantinya akan memberikan dampak positif terhadap penderita penyakit nyeri kepala, dimana mengkombinasikan dua tehnik yaitu antara teknik bernafas (pranayama), relaksasi serta latihan peregangan atau postur (asana). (Sindhu, 2015). Hasil penelitian yang dilakukan oleh Lin, Huang, \& Yeh (2015), dengan tujuan penelitian untuk mengetahui pengaruh latihan yoga hatha terhadap stres atau nyeri kepala, adaptasi stres atau nyeri kepala dan denyut nadi pada tenaga 
kesehatan dibidang kejiwaan dengan randomized control trial yang dilakukan pada 30 sampel pada kelompok kontrol dan intervensi. Hasil didapatkan bahwa terdapat pengaruh yoga terhadap stres atau nyeri kepala, adaptasi stres atau nyeri kepala dan denyut nadi $\mathrm{p}$-value $<\alpha=0,05$ ( $\mathrm{p}$ value $<0,002)$.

Hal ini karena terapi dengan yoga asanas tidak hanya menghilangkan pusat rasa sakit sementara saja, namun juga mencegahnya dengan menangani sumber masalah dari nyeri kepala ini. Yaitu, dengan manajemen stress pikiran melalui pranayama dan merelaksasikan otot-otot yang menyebabkan ketegangan yang berakibat pada rasa sakit kepala. Terapi yoga asanas memberi efek penyembuhan jangka panjang karena memusatkan pada pusat masalah dari sakit kepala dibanding dengan menghilangkan rasa nyeri sementara. Dengan pose tertentu, otot leher, punggung yang rileks, aliran darah yang lancar, serta perasaan yang positif dapat meredam penyebab-penyebab dari sakit kepala. Diakhiri dengan meditasi dan olah nafas akan menguatkan fokus pikiran sehingga stress dapat di manajemen dengan baik dan mencegah sakit kepala tersebut muncul kembali.

\section{DAFTAR PUSTAKA}

Anurogo, D. 2012, 'Penatalaksanaan Migren', vol. 39, no. 10, pp. 731-737.

Bigal. M. E \&Lipton. R.B. (2006). Migrain at all ages. Journal of Current Science.

IASP 2012, 'Epidemiology of headache', Cephalalgia. doi: 10.1046/j.1468-2982.1995.

Jatmiputri, S. S. 2016, 'Pengaruh Stres Kerja dan Nyeri Kepala Pada Pekerja Ground Handling (Studi Kasus di Bandara Ahmad Yani Semarang) Laporan Hasil'. 